\title{
Fazendo e desfazendo gênero em Billy Elliot
}

\section{Doing and undoing gender in Billy Elliot}

https://doi.org/10.34112/2317-0972a2018v36n73p51-67

ANDERSON FERRARI ${ }^{1}$

Marcos Lopes de Souza ${ }^{2}$

Roney Polato de Castro ${ }^{3}$

Resumo: O convite deste artigo é colocar o pensamento sob suspeita: por que se pensa o que se pensa? Como os pensamentos organizam as ações no mundo e as relações pessoais? São estas questões que estão no foco das problematizações que se tomam como desafio a partir do filme Billy Eliot, a história de um menino que insiste em romper com a tradição familiar de lutadores de boxe, para se arriscar no balé. A partir deste drama cinematográfico, discute-se a construção dos gêneros pela perspectiva de Judith Butler, ou seja, como o masculino pode ser entendido dentro do projeto de fazer e desfazer o gênero.

Palavras-chave: Gênero; subjetivações; educação.

AвSTRACT: Our interest in this article is to place thought under suspicion: why do we think what we think? How do our thoughts organize our actions in the world and our personal relationships? These questions are the focus of the problematizations that we have taken as a challenge from the film Billy Eliot, the story of a boy who insists on breaking the familiar tradition of boxing fighters to take a chance at the ballet. From this cinematographic drama we will discuss the construction of genders from the perspective

1. Universidade Federal de Juiz de Fora, Juiz de Fora, MG, Brasil.

2. Universidade Estadual do Sudoeste da Bahia, Jequié, BA, Brasil.

3. Universidade Federal de Juiz de Fora, Juiz de Fora, MG, Brasil. 
of Judith Butler, that is, how the masculine can be understood within the project of doing and undoing gender.

KEYWORDS: Gender; subjectification; education.

\section{INTRODUÇÃO}

Segundo Butler (2007), a prática sexual tem o poder de desestabilizar o gênero. Podemos pensar que a sexualidade normativa consolida o gênero normativo, o que significa dizer que há um certo embaralhamento entre gênero e sexualidade. Um homem se torna homem na medida em que se enquadra ou funciona como homem na estrutura heterossexual dominante. Nesse sentido, qualquer coisa que seja entendida como ameaça a este modelo - gênero e sexualidade normativos - causa medo e ansiedade nos sujeitos. Esses sentimentos se voltam a algumas pessoas que associam o "medo" da homossexualidade ao medo de perder o lugar que se ocupa no gênero, como se a homossexualidade representasse a expulsão ao gênero, ou seja, como se constituísse um terceiro gênero.

O grau de refinamento que organiza nossa sociedade a partir do gênero nos leva a problematizar que não somente as práticas sexuais desestabilizam o gênero, mas também os componentes da sociedade, em um binarismo em que ser homem e mulher significa uma série de comportamentos, atitudes, constituição corporal, práticas esportivas, roupas, enfim, um conjunto que nos leva a considerar os gêneros como uma forma de se fazer (BUTLER, 2004). Os gêneros seriam resultado de atividades performativas incessantes, sem que tenhamos consciência ou mesmo vontade, mas que também não significa que seja automática ou mecânica. $O$ gênero não se faz isoladamente e sozinho, ele está sempre se fazendo com/ou para o outro, ainda que o outro seja somente imaginário. Assim, numa sociedade em que a heterossexualidade é a norma, vigiar o gênero é uma forma de afirmar a heterossexualidade.

É esse jogo entre o masculino como construção da heterossexualidade e o entendimento das homossexualidades como ameaça a esse modelo valorizado e normativo que vamos tomar como foco da discussão deste artigo. Para isso, vamos tomar como inspiração o filme Billy Elliot, que conta a trajetória de um menino inglês, morador de uma cidade do interior da Inglaterra, com forte representação do masculino ligado aos trabalhadores do carvão, num período histórico de enfrentamento entre essa categoria de trabalhadores e o governo neoliberal de Margareth Thatcher. É nesse contexto restrito de confronto e luta que vai se constituindo o que é ser homem: um 
menino que vive numa família basicamente constituída de homens e com tradição de envolvimento com o boxe. Pai e irmão que trabalham nas minas de carvão e estão à frente de uma greve cada vez mais tensa e Billy, que pouco a pouco vai se distanciando desse universo, rompendo com a tradição e se interessando pelo balé.

O conflito cinematográfico, portanto, gira em torno dessa disputa entre manter a tradição familiar de homens lutadores de boxe ou romper com ela. Mais do que isso, manter uma atividade que constitui o gênero nessa comunidade ou desestabilizar o gênero, ao se aproximar do balé, uma atividade que traz uma certa forma de conhecer, vinculada ao gênero oposto.

\section{FAZENDO GÊNERO}

É importante dizer que o gênero é uma categoria de análise que investiu na ideia de que a desigualdade entre homens e mulheres se constrói em relação, e, portanto, não é possível falar de homens sem olhar para as mulheres e vice-versa. As desigualdades entre homens e mulheres são construções da sociedade e da cultura (SCOTT, 1995). Nesse investimento de construção nos gêneros, as masculinidades e as heterossexualidades nos convidam a colocar sob suspeita nossas formas de pensar, saber e agir. Se o gênero masculino é socialmente construído, ele está sempre sujeito a construções e desconstruções, a um fazer e desfazer constante, ao contrário do que somos levados a pensar a partir do masculino como normalidade e naturalidade. Estamos investindo nesse fazer masculino. E nesse fazer masculino estamos também fazendo outras identidades, representações e sujeitos. Afirmar e fazer o masculino parece estar diretamente ligado ao fazer e recusar outras formas de ser, como, por exemplo, as homossexualidades. Isso porque afirmar e fazer o masculino é afirmar e fazer as heterossexualidades. $\mathrm{O}$ gênero emerge como uma forma rígida da sexualidade, constituindo a desigualdade entre os homens: o heterossexual e o homossexual.

A hierarquia sexual cria e consolida o gênero (BUTLER, 2007). Na primeira cena em que Billy aparece, durante uma luta de boxe, ele parece ensaiar uma dança no ringue, para perplexidade do adversário e revolta do treinador, que o repreende: "Não fique aí parado, Elliot. O que você está fazendo? Bate nele. Isso é um combate de homem a homem e não uma aula de balé. Acerte ele com força, parece até uma menininha". Não se comportar como se deseja em um treino de boxe, em que se espera o confronto e a agressão entre meninos, ameaça a permanência no gênero. Para trazê-lo para o comportamento adequado, o treinador o expulsa do gênero masculino. Dizer que 
parece uma "menininha" parece funcionar como uma busca pela correção. O pai, que assistia a tudo, reforça a postura do treinador: "Bate nele, filho, bate". Nessa disputa entre a dança e a luta, o menino é atingido pelo adversário e vai à lona. Vence o boxe. O espaço masculino é preservado, demonstrando que quem não se enquadra, perde. A ação é encerrada com a conclusão do treinador: "Meu Deus!!! Billy Elliot. Vocêé uma vergonha para essas luvas, para o seu pai e para as tradições do boxe".

Em meio ao encantamento pelo balé e a vergonha por estar num espaço feminino e "saber" o que se diz de meninos que fazem dança, Billy se mostra indeciso em assumir que está mais interessado pela dança, ao que a filha da professora tenta convencê-lo: "Muitos meninos fazem balé, sabia?", Billy não se dá por convencido: "É mesmo? Meninosfazem balé? Aqui? Quem faz?". Ao que a menina responde: "Aqui não, mas muitos homens fazem balé." Billy os enquadra, num certo embaralhamento entre gênero e sexualidade: "Bichas!!!". "Bichas" parece dizer "não são homens", de maneira que se fazer do gênero masculino é se afastar do universo feminino em que está o balé. Na mesma linha do convencimento, a professora também tenta conquistar Billy para a dança: "Você vai nos dar sua presença na próxima semana?". E Billy expressa seu receio: "Sabe? É que eu me sinto um maricas."

Ele inicia uma aproximação ao balé escondido do pai, não comparecendo às aulas de boxe, até que o pai o descobre em uma aula, junto com todas as meninas:

Você! Saia agora.

O desgosto e a raiva do pai ao ver o filho cercado por meninas bailarinas é a expressão que demonstra a hierarquia do gênero, em que fazer algo apropriado e "exclusivo" a meninas é ser menos. Já em casa, pai e filho travam uma disputa em torno do que representa para aquela família ter um filho fazendo balé, rompendo com a tradição de homens que fazem boxe. Uma disputa que traz à tona formas de conhecer. Estão em dois cantos da mesa, pai e filho, sob olhar atento da avó, que parece assistir a uma partida de tênis, olhando para cada um dos lados, à medida que a disputa se transforma em trocas de acusações.

Pai: Balé!

Billy: Qual é o problema com o balé?

Pai: Qual é o problema com o balé!?

Billy: É perfeitamente normal.

Pai: Perfeitamente normal?

Avó: Eu já fiz balé. 
Billy: Está vendo?

Pai: Para sua avó. Para meninas e não para meninos. Meninos jogam futebol, lutam boxe ou luta livre e não esta droga de balé.

(...)

Billy: Eu não vejo nada de errado.

Pai: Você sabe muito bem o que há de errado.

Billy: Não sei, não.

Pai: Sabe, sim.

Billy: Não sei, não.

Pai: Você sabe muito bem, sim! Quem você pensa que eu sou? Você sabe muito bem.

Billy: O quê? O que está tentando me dizer, pai? Não são só para bichas, pai. Alguns bailarinos são fortes como atletas.

O balé vem sendo enquadrado como atividade feminina. Faz parte das atribuições sociais historicamente constituídas e culturalmente determinadas que investem em um binário de gênero. O estranhamento do pai de Billy, portanto, se ampara nesta lógica: se o balé é para mulheres, logo, homens que dançam balé estariam "traindo" a legitimidade do seu gênero, portanto, seriam bichas. E por isso, Billy estaria "pedindo uma surra!”. Apesar do gosto pela dança, o menino se coloca em constante questionamento, tendo em vista essa mesma lógica: deveria seguir as tradições e dedicar-se ao boxe ou seguir em frente com algo que lhe dá prazer? Billy vai se entregando ao balé aos poucos e gradativamente substitui as velhas luvas de boxe herdadas do pai pelas sapatilhas doadas pela professora. Antes da revelação, quando o pai vai à academia e presencia o filho em uma performance, Billy deveria manter o balé na clandestinidade: era preciso esconder da família o que fazia na academia, esconder as sapatilhas debaixo do colchão ou dentro das calças, evitar movimentos que pudessem denunciar seu interesse pela dança.

Encontramos em algumas pesquisas argumentos para pensar a relação entre o balé e os gêneros. Em geral, os estudos apontam que o balé clássico vem sendo compreendido como atividade tipicamente feminina. Mas nem sempre foi assim. Estudos como os de Melo e Lacerda (2009), Andreoli (2011), Assis e Saraiva (2013) e Nascimento e Afonso (2013) apontam que, no seu surgimento nas cortes e aristocracias italiana e, posteriormente, francesa, em meados do século XV, o balé era uma atividade masculina. Prática até então desempenhada pelos homens da nobreza, foi lentamente se deslocando das cortes para os palcos; portanto, tornando-se mais que uma dança social: 
uma atividade refinada, exercida por bailarinos profissionais. Antes das Revoluções Francesa e Industrial não havia sinal de preconceitos contra os bailarinos. O balé foi lentamente sendo conquistado pelas mulheres, tornando-se uma arte para ambos os gêneros. Porém, com as novas construções simbólicas da modernidade, os homens tornaram-se menos bem-vindos nesse território, que seria um desprestígio relativo às novas construções sobre o corpo: até então ligado ao prazer, passou a ser instrumento de produção. Sendo uma profissão com baixa remuneração, a dança foi progressivamente se definindo como "reino das mulheres", pois não era atrativa aos homens. Como argumentam Melo e Lacerda (2009), o corpo masculino foi desaparecendo dos palcos da dança, ao mesmo tempo em que passou a ser cada vez mais celebrado nos esportes. Além disso, a incorporação do romântico ao balé favoreceu a entrada em cena das bailarinas, pois envolvia sensualidade e leveza, características culturalmente atribuídas às mulheres (NASCIMENTO; AFONSO, 2013).

Já nos fins do século XVII, a cultura ocidental passou a relacionar o homem que dança profissionalmente com a homossexualidade e a efeminação, algo que ainda nos dias atuais interpela os meninos a não se aproximarem do balé. Portanto, além de uma associação do corpo masculino com a produtividade para o trabalho, tornando o balé uma atividade economicamente desfavorecida, a sua demarcação como atividade feminina faz com que o interesse dos meninos/homens seja motivo para a vergonha, constrangimento, injúria e violência, como se sua masculinidade ficasse comprometida socialmente. Tal argumento, porém, parece não encontrar lugar no filme: ir para o balé, aperfeiçoar as suas habilidades, poderia levar Billy para outro lugar, longe das condições socioeconômicas pouco favorecidas, ou seja, uma oportunidade de mudar de vida. O enredo dialoga com a pesquisa de Nascimento e Afonso (2013), realizada com meninos bailarinos de uma cidade do interior do Rio Grande do Sul: apesar dos preconceitos relativos à sexualidade, o balé constituía-se naquele contexto como uma forma de valorização social, de "vencer barreiras" e fugir dos constrangimentos econômicos e sociais, já que os meninos faziam parte de comunidades pouco privilegiadas economicamente.

Souza (2006) nos ajuda a pensar que as representações culturais de gênero e sexualidade que atravessam o balé operam como potentes pedagogias produzindo e regulando os sujeitos, seu entendimento de si mesmos, moldando suas ações e necessidades. Ao observarmos as cenas do filme, chama a atenção a marcação do balé construída pela oposição ao boxe: de um lado, uma professora e suas alunas vestidas com malhas e sapatilhas cor-de-rosa, movimentando-se delicadamente e 
coordenadamente, ao som da música; de outro, no ringue, meninos sem camisa, buscando nocautear o adversário, de forma agressiva e competitiva. Com esse argumento, investimos na ideia de que as representações culturais ali materializadas se impõem por saberes construídos em outras instâncias (pela ciência, pela religião, pela família) e instauram relações de poder, nas quais sempre é possível resistir. Billy, de modo conflituoso, sempre em negociação com os saberes que vinham moldando sua subjetividade, ultrapassa a fronteira (ou coloca-se na fronteira), fragiliza a masculinidade construída na luta, na tradição familiar, tornando-a porosa às feminilidades ali circulantes. Mesmo que fosse uma atividade considerada feminina e, portanto, envolver-se com ela representasse uma ameaça à heterossexualidade, o menino provoca uma ruptura, produz uma descontinuidade nas construções de gênero que normatizam as relações sociais das quais é parte.

As representações do balé como prática feminina parecem não constituir um obstáculo para Billy tornar-se um bailarino, ainda que isso implique um constituir-se conflituoso, exigindo constantes negociações. Inspirados em Britzman (1996), argumentamos que as identidades de gênero não existem sem negociação e construção, não estão prontas e acabadas à espera de serem assumidas. Mesmo as identidades mais normativas não são facilmente assumidas. Seriam, portanto, instáveis, contraditórias e não finalizadas. Podemos argumentar que os gêneros se constroem por reiterações contínuas, mediante interpretações em atos das normas de gênero, como uma recitação dos códigos socialmente investidos como naturais. Há, portanto, investimentos discursivos contínuos que se dirigem à preparação dos corpos para que desempenhem com êxito as identidades. Nesse sentido, o boxe representaria parte da educação de Billy para assumir certa masculinidade, um investimento que, junto com outras estratégias discursivas e práticas, visam construir um homem. A construção da identidade de gênero é um processo de longa e ininterrupta duração, que "adquire vida através das roupas que compõem o corpo, dos gestos, dos olhares, ou seja, de uma estilística definida como apropriada” (BENTO, 2014, p. 109). Era apropriado que Billy utilizasse as luvas de boxe e não as sapatilhas de balé. A repetição e a reiteração das normas de gênero sustentam e reforçam as identidades hegemônicas, porém, como argumenta Bento (2014), há repetições descontextualizadas ou subversivas do "contexto natural dos sexos" que possibilitam a emergência de práticas para transformar o gênero. Ao assumir o propósito de tornar-se bailarino, Billy subverte as normas e passa a negociar outras expressões de gênero possíveis. 
Pesquisas mostram que ainda hoje os meninos que se interessam pelo balé enfrentam inúmeros preconceitos, na família e nas demais instâncias sociais. Nascimento e Afonso (2013), ao entrevistar familiares (especialmente mães) de meninos que frequentam um projeto de balé, constataram que todos sofreram algum tipo de preconceito, embora, nesse caso, a família não demonstrasse se coadunar com isso. Em sua pesquisa, demonstraram que os meninos tinham apoio de suas famílias para ser bailarinos. Souza (2016), entrevistando bailarinos profissionais, aponta para o contrário: os constrangimentos, a rejeição e a falta de incentivo das famílias. Além disso, sua pesquisa nos mostra que o valor social dos bailarinos profissionais está associado ao sucesso, às premiações, ao desenvolvimento de uma técnica impecável, o que, inclusive, poderia colocá-los em outras posições (instrutores, coreógrafos). No filme, o incentivo para que Billy continuasse com as aulas era a constatação, pela professora, de seu talento, algo que o levaria para uma famosa companhia de balé em Londres. As cenas finais mostram Billy, muito tempo depois, apresentando-se como bailarino principal, sendo assistido pela família e pelo amigo de infância. A ideia do sucesso, da habilidade parece figurar como uma exceção: somente os naturalmente habilidosos, aqueles que teriam um "talento nato", poderiam tornar-se bailarinos? Ou seja, nesse caso, os bailarinos seriam bonificados e perdoados pela traição de seu gênero?

Por outro lado, enquanto prática social e histórica, ao ser reivindicado pelas mulheres, o balé passa a ser mais um campo de enquadramento e de investimento numa concepção binária de gênero, reforçando e sendo reforçado por representações normativas sobre homem e mulher. Como argumentam Melo e Lacerda (2009), no pas de deux, o homem deve ser forte, galante, elegante. Seus músculos devem sustentar e controlar os movimentos femininos, auxiliando a mulher na demonstração de sua graciosidade e desenvoltura. Assim, mesmo o balé, em que homens e mulheres partilham o palco, não significaria a construção de outros modelos de masculinidades e feminilidades. Os corpos devem ter, portanto, uma funcionalidade clara: homens devem exibir atitude, demonstrar postura propositiva; mulheres, ao contrário, não devem macular sua feminilidade, preservando a leveza e a suavidade. No confronto com o pai, quando este descobre o motivo de o filho estar ausente às aulas de boxe, Billy argumenta: "Alguns bailarinos são fortes como atletas!". A associação dessa dança com a homossexualidade poderia, talvez, ser rompida ou amenizada pela associação do balé com a força e com o esporte. Se a tradição impelia o pai e o irmão (e a comunidade, de modo geral) a entender que o destino dos meninos como Billy 
era tornarem-se fortes, agressivos, bons mineradores, pensar o balé a partir dessa associação pode ter contribuído para que as tensões se afrouxassem.

\section{Desfazendo GÊNERO}

A premissa de que o sexo é natural, uma essência biológica, e de que o gênero é construído social e culturalmente convenceu e ainda convence, em muitos casos, as/os estudiosas/os e muitas/os feministas que se enveredam pelas investigações e militância nesta área, inclusive nós mesmos também já fomos fisgados por este pensamento. É recente a preocupação em desconstruir essa compreensão de sexo e gênero. Para Butler (2012), algumas compreensões de gênero como produção cultural indicam uma fixidez no seu significado, ao colocarem os corpos como um meio passivo nos quais se inscrevem os significados culturais de gênero. Ela defende os corpos e os sexos também como construções que não existem anteriormente às marcas de gênero. Em suas palavras:

O sexo não deve ser meramente concebido como a inscrição cultural de significado num sexo previamente dado (uma concepção jurídica); tem de designar também o aparato mesmo de produção mediante o qual os próprios sexos são estabelecidos. Resulta daí que o gênero não está para a cultura como o sexo para a natureza; ele também é o meio discursivo/cultural pelo qual "a natureza sexuada" ou um "sexo natural" é produzido e estabelecido como "pré-discursivo", anterior à cultura, uma superfície politicamente neutra sobre a qual age a cultura (BUTLER, 2012, p. 25, destaques da autora).

Essas reflexões nos ajudam a problematizar o quanto o sexo é posto em um lugar confortável, inquestionável, algo dado a priori e, ao mesmo tempo, ajudam a perceber o quanto precisamos des-estabilizar, des-construir, des-fazer os gêneros e os sexos que são continuamente produzidos e também colocá-los sob suspeita. Retomando o filme Billy Elliot, trazemos algumas cenas que nos ajudam a pensar des-fazer o gênero.

Em diferentes momentos do filme é apresentada a relação entre Billy e seu colega Michael Caffrey, nos dando pistas de como eles problematizam as produções dos gêneros e as des-fazem. Uma delas se deu no momento em que Billy vai à casa de Michael e, ao abrir a porta, ele se depara com o amigo usando um vestido azul da irmã. Ele se assusta, e Michael o interroga se vai ou não entrar. Antes de adentrar a casa, Billy olha ao redor, talvez se assegurando de que ninguém os esteja 
observando. Já na casa, Billy, ainda intimidado, pergunta ao amigo sobre o vestido que está usando e ele diz que é da irmã, mas que ela não sabe. Inclusive Michael mostra a Billy um vestido vermelho e o convida a vestir também, mas ele recusa. Billy o questiona se ele está bem e o porquê de ele estar fazendo aquilo e ele diz estar experimentando. É interessante perceber como Michael vai atravessando as delimitações socioculturais de gênero: ele as cruza sem receios ou insegurança, $o$ faz de forma espontânea, apesar de isso acontecer no espaço da casa. Poderíamos analisar como Michael escapa, foge às normas e não se conforma com elas, rompe as regras, põe-se à deriva e convida o amigo para se arriscarem (LOURO, 2008).

Ainda na cena, Michael vai até o espelho e passa o batom e, em seguida, pede para Billy sentar na cama e também coloca o batom nele. Billy ainda insiste em perguntar se não haverá problemas em fazerem aquilo. Michael diz: "Não seja bobo. Meu pai sempre faz isso". Billy, espantado, pergunta se o pai veste a roupa da mãe, e ele responde: "Só quando ele acha que todos saíram". Diferente de Michael, Billy fica apreensivo e receoso em transgredir as normatizações de gênero e, em vários momentos, interpela o amigo: "O que você está fazendo? De quem é esse vestido? Ela deu pra você? Você está bem? Não vamos ter problemas?". O discurso binário e restrito de gênero que, a princípio, nega ao homem o uso do vestido ou mesmo do batom, captura Billy, o faz se incomodar com a situação em que se depara com o amigo; duvida dela, tem medo de ser punido por estar atravessando as fronteiras de gênero. E leva-o a questionar, inclusive, a possível sanidade do amigo.

A produção do masculino em nossa sociedade se faz pelo combate a tudo aquilo que esteja associado à mulher (no caso, o batom e o vestido). Na socialização entre os homens, conforme Welzer-Lang (2001, p. 465), "o feminino se torna até o pólo de rejeição central, o inimigo interior que deve ser combatido sob pena de ser também assimilado a uma mulher e ser(mal) tratado como tal".

Todavia, Billy também rompe de alguma forma as normatizações, se permite experimentar outras coisas, deslocando o gênero para o qual foi insistentemente produzido. Ele cede, foge à vigilância, ao deixar o amigo passar o batom nele. Michael expõe que o pai também transgride essas normas, usando o vestindo e o batom, mesmo que isso aconteça em momentos que ele acredita não ter ninguém em casa.

Uma das falas que encerra esta cena é quando Billy questiona o colega: "Maycon, você acha que ser bailarino é melhor do que ser mineiro?". O amigo disse não saber. Billy começa a pensar o balé como uma possibilidade em sua vida e não algo indesejável. A dúvida o mobiliza a refletir que o seu destino não precisa estar nas minas 
de carvão, como a princípio ele pensava. Mesmo ainda não sabendo o que deseja, ser bailarino, algo que anteriormente ele enquadrava como sendo para as meninas ou para as bichas, pode ser um caminho a ser seguido, apesar dos estereótipos que Billy ainda carrega em seus discursos.

Há outra cena do filme que também nos mobiliza a pensar sobre as marcas de gênero e as produções da sexualidade. Após um dia de treino com a professora Sandra, Billy está trocando de roupa e Debbie, filha de Sandra - a professora de balé -, senta ao lado dele e inicia a conversa:

Debbie: Quando vai ser o teste?

Billy: Amanhã de manhã.

Debbie: Eu vou sentir sua falta.

Billy: Quem você acha melhor: Fred Astaire ou Ginger Rogers?

Debbie: Billy, você está a fim de mim?

Billy: Eu não sei. Eu nunca pensei nisso.

Debbie: Se você quiser, eu mostro minha perereca.

Billy: Não, não precisa.

Nesta passagem, Debbie quer saber se Billy sente algum desejo e sentimento por ela. Ele diz não saber, não ter pensado sobre isso, e ela insiste, inclusive perguntando se ele não quer ver sua perereca, mas Billy diz não precisar e vai embora. Podemos problematizar que Billy não se deixa capturar pelo discurso de afirmação de um modelo de masculinidade que requer a prova contínua de que é heterossexual e sente desejo por mulheres. Não sentir desejo ou atração por uma garota - no caso, Debbie - não incomoda Billy, o que para o discurso heteronormativo poderia gerar uma desconfiança em relação à sua heterossexualidade. Aqui ele poderia estar sendo posto em xeque por dizer não a uma garota. Para a heteronormatividade, todas as pessoas seriam, a priori, heterossexuais, pois a heterossexualidade é tida como a sexualidade natural, universal e normal. Nesta lógica, é entendida como regime político e social que regula a vida das pessoas. Quem ousa entrar em desacordo com as normas de sexo/gênero/sexualidade é questionado/a e, muitas vezes, posto/a à margem (MISKOLCI, 2009).

Mais uma vez pensando os processos de desconstrução dos sexos, gêneros e das sexualidades, em outra passagem do filme, no dia de Natal, Billy e Michael estão 
fazendo um boneco de neve quando Billy diz que suas mãos estão geladas por conta do frio, e Michael as coloca em seu casaco:

Billy: O que está fazendo?

Michael: Nada, só aquecendo suas mãos.

Billy: Você é bicha?

Michael: O que faz você pensar isso?

Billy: Pegou minhas mãos.

Michael: Eu gosto disso. (Dá um beijo no rosto de Billy).

Billy: Só porque eu gosto de balé não significa que eu seja bicha.

Michael: Não conta pra ninguém.

Billy: Vamos embora.

Nesta cena temos dois momentos em que Michael toca Billy: primeiramente, ao pegar as mãos dele e colocar dentro do seu casaco para aquecê-lo, e depois, ao beijar seu rosto. Esta passagem nos faz pensar o quanto a produção dos meninos e de seus corpos se dá pelo distanciamento entre si e pela não demonstração de carinho, cuidado e afetividade, incluindo o não se tocar. De acordo com Louro (1999), há um controle e quase impedimento sobre as exposições físicas de amizade e de afeto entre os rapazes. Para ela, essa vigilância intensa sobre a manifestação de afetividade entre homens, geralmente, não acontece da mesma forma com as mulheres. $\mathrm{O}$ discurso de que dois homens não podem e não devem trocar carícias é reiterado, várias vezes, em nossa sociedade, e já presenciamos nas mídias situações de agressão e violência contra aqueles que subverteram essa norma. Casos de pai e filho que foram violentados fisicamente por estarem abraçados e de irmãos que foram assassinados por terem dançado juntos em uma festa de rua. Nessas situações os homens foram punidos por des-fazerem as normas de gênero, questionarem 0 lugar do homem e do masculino e produzirem outros gêneros.

Para a norma, o toque entre homens é autorizado, caso se trate de brigas ou lutas - aliás, em algumas situações, os garotos devem se agredir em prol da conquista de espaços e de lugares e da afirmação de um determinado modelo de masculinidade. O próprio Michael, no início do filme, indaga Billy sobre os treinos de boxe, dizendo ao amigo que essas aulas são bobagens e por isso não participa. Segundo Michael: " $E$ ridiculo ficar batendo nas pessoas. Enfim, não sei porque se interessa". Michael quebra essa normalização, ao pensar outras possibilidades de gênero, não se conformando 
com este lugar posto para o homem e para o masculino em contraponto à mulher e ao feminino, desnaturalizando-o.

Recuperando o diálogo, Billy diz a Michael que o gosto dele por balé não o faz bicha. Não vincula, portanto, o lugar do balé à homossexualidade, como ainda é feito pelo discurso normativo. Billy não atrela seus desejos e afetos sexuais ao balé, ele os separa, os distancia, os desagrega. Para o discurso normativo, o balé desviaria Billy do seu destino já traçado, tiraria sua masculinidade, aproximá-lo-ia do feminino e o tornaria gay. Esse medo da homossexualidade orienta muitas famílias a evitar que seus filhos experienciem as várias expressões da dança. Tendo como parâmetro os escritos de Butler (1999), constatamos que a produção dos sexos e dos gêneros está vinculada às práticas discursivas que se constituem como normas regulatórias, continuamente reiteradas e (re)produzidas para a nomeação, a diferenciação e o controle dos corpos, materializando a diferença sexual em prol do estabelecimento de uma ordem heterossexual a qualquer custo. A heterossexualidade passa a ser a lógica social que orienta as produções dos sexos, dos gêneros e das sexualidades. No caso de Billy, por ele ter afinidade com balé, o seu sexo/gênero e sua heterossexualidade são questionados e ele se perturba mais isso quando diz que gosta de balé, mas não é gay. Este episódio nos possibilita pensar que assumir um determinado gênero ou marcas associadas a uma expressão de gênero não pressupõe que esta pessoa tenha ou se envolva em uma determinada prática sexual (BUTLER, 2014).

Por outro lado, esse fantasma do medo e da rejeição da homossexualidade ou de ser visto como gay ronda Billy, tanto que, no dia do ensaio para o Royal Ballet School, ele se incomoda com um colega que procura consolá-lo após o teste, se enraivece, pede para o garoto soltá-lo, lhe dá um soco no rosto e diz: "Olha vai se danar, tá bom! Sua bicha louca!". Apesar de Billy estar em um teste para a escola de balé, ele reitera as normas regulatórias que associam o balé a algo feminino e, portanto, aqueles garotos que se enveredam para esta dança seriam lidos como gays, aliás, não qualquer gay: nos dizeres de Billy, uma bicha louca, uma homossexualidade extravagante. Essa violência que Billy praticou ao agredir o colega e nomeá-lo de bicha louca é uma forma pela qual o heterossexismo e a heteronormatividade operam, produzindo naqueles/as que transgridem as normatizações de sexo/gênero/ sexualidade, o medo de serem violentados/as (MISKOLCI, 2013).

Voltamos à cena de Billy e Michael na noite de Natal. Após o diálogo, eles vão ao ginásio e lá Billy entrega um saiote para Michael e começa a ensinar-lhe alguns movimentos do balé. Os dois se divertem dançando, quando Jackie, o pai de Billy, 
e o professor de boxe chegam. Ao vê-lo, Billy interrompe a dança e o encara. Jackie olha para Michael, que rapidamente tira o saiote. Billy não fala nada, se entrega à dança até o final da música. Ele não mais silencia, resiste aos olhares de vigilância e não vai embora, como da outra vez. Ele desafia o olhar do pai e passa a dançar os passos que aprendeu nas aulas de balé com a sua professora Sandra. A identificação com o balé fala mais alto, e ele não sucumbe aos discursos normativos. Por mais investimentos que tenham sido feitos para a sua desistência, ele se arrisca e ousa desviar-se por outros caminhos que não o das minas de carvão.

A história de Billy nos convida a pensar a impossibilidade dos gêneros como categoria homogênea e as masculinidades como essência. Não se nasce homem e nem mulher, vamo-nos tornando esses seres com gênero e sexualidade no contexto social, histórico e cultural, de maneira que só podemos falar de homens e mulheres no plural. Billy demonstra a força do sujeito em pensar e colocar em circulação outras formas de ser e estar no mundo, a partir da problematização daquilo que insiste em nos controlar e docilizar como detentores de corpos masculinos e femininos.

\section{ConsideraÇões finais}

Trabalhar com um filme para problematizar nossas formas de pensar e agir é considerar que o cinema é um artefato cultural que investe em pedagogias culturais capazes de construir homens e mulheres em relação. Nossos processos de subjetivação são educativos, formas de ser que vamos aprendendo ao longo da vida, circunscritos em contextos culturais com seus saberes e poderes. Nesse sentido, todos os espaços em que circulamos são preenchidos por diferentes saberes, que ora dialogam, ora não, mas sempre investem em sujeitos de determinados tipos. Somos resultados desses processos e discursos educativos. No filme acabamos torcendo pela vitória do balé sobre o boxe, de Billy sobre o seu "destino manifesto", enfim, de outras formas de ser homem. O cinema serve, em certa medida, para o desprendimento da realidade. Vivemos outras formas de pensar e de agir.

Fazer e desfazer o gênero é um jogo de força e poder que organiza os sujeitos, o "eu" e o "outro". Não é possível escapar do gênero, ele é um organizador social de inteligibilidade da realidade e dos sujeitos. Mas isso não significa que estejamos sujeitos a formas já definidas de gêneros. Neste artigo, defendemos, a partir da história de Billy Eliot, que os gêneros podem ser desconstruídos, para que possamos colocar em vigor diferentes formas de ser homens e mulheres ou mesmo sair deste binarismo de gênero 
que tanto nos marca e ocupar a fronteira que, muitas vezes, é vista como ameaça, perigo, lugar de passagem e de oposição entre os gêneros. Queremos estabelecer outras formas de pensar e agir a partir da ação problematizadora de nós mesmos: porque pensamos o que pensamos? Como vamos construindo nossas formas de pensar? Nossas formas de pensar têm a ver com a história do pensamento. E problematizar as relações de gênero e as formas como as pessoas se constituem como homens e mulheres é colocar essa história do pensamento sob suspeita, de maneira que possamos pensar de outra forma e colocar em circulação outras formas de ser e estar no mundo.

\section{REFERÊNCIAS}

ANDREOLI, G. S. Representações de masculinidade na dança contemporânea. Movimento, Porto Alegre, v. 17, n. 01, p. 159-175, jan./mar. 2011. Disponível em: <http://seer.ufrgs.br/index.php/ Movimento/article/view/16175/12947>. Acesso em: 05 ago. 2016.

ASSIS, M. D. P.; SARAIVA, M. C. O feminino e o masculino na dança: das origens do balé à contemporaneidade. Movimento, Porto Alegre, v. 19, n. 02, p. 303-323, abr./jun. 2013. Disponível em: <http://seer.ufrgs.br/Movimento/article/viewFile/29077/25265>. Acesso em: 05 ago. 2016.

BENTO, B. A reinvenção do corpo: sexualidade e gênero na experiência transexual. 2. ed. Natal: EDUFRN, 2014.

BRITZMAN, D. O que é essa coisa chamada amor: identidade homossexual, educação e currículo. Educação \& Realidade, Porto Alegre, Faculdade de Educação, UFRGS, v. 21, n. 1, p. 71-96, jan./jun. 1996.

BUTLER, J. Corpos que pesam: sobre os limites discursivos do sexo; In: LOURO, G. L. (Org.). O corpo educado: pedagogias da sexualidade. 2. ed. Belo Horizonte: Autêntica, 1999. p. 151-165.

. Deshacer el género. Barcelona: Paidós, 2004. . El género en disputa. El feminismo y la subversión de la identidad. Barcelona: Paidós, 2007. .Problemas de gênero: feminismo e subversão da identidade. Trad. Renato Aguiar. 4. ed. Rio de Janeiro: Civilização Brasileira, 2012.

. Regulações de gênero. Cadernos Pagu, n. 42, p. 249-274, 2014.

LOURO, G. L. Pedagogias da sexualidade. In: LOURO, G. L. (Org.). O corpo educado: pedagogias da sexualidade. Belo Horizonte: Autêntica, 1999. p. 7-34.

.Um corpo estranho - ensaios sobre sexualidade e teoria queer. 1. ed. 1. reimp. Belo Horizonte: Autêntica, 2008.

MELO, V. A.; LACERDA, C. Masculinidade, dança e esporte: "Jeux" (Nijinsky, 1913), "Skating Rink” (Borlin, 1922) e "Le Train Bleu” (Nijinska, 1924). Revista Brasileira de Ciência do Esporte, Campinas, v. 30, n. 3, p. 45-62, maio 2009. Disponível em: <http://www.revista.cbce.org.br/index. $\mathrm{php} / \mathrm{RBCE} /$ article/viewFile/221/382>. Acesso em: 05 ago. 2016.

MISKOLCI, R. A teoria queer e a sociologia: o desafio de uma analítica da normalização. Sociologias, Porto Alegre, ano 11, n. 21, p. 150-182, jan./jun. 2009. 
. Teoria queer: um aprendizado pelas diferenças. 2 ed. rev. e ampl., 1. reimp. Belo Horizonte: Autêntica; UFOP - Universidade Federal de Ouro Preto, 2013.

NASCIMENTO, D.E.; AFONSO, M. R. A participação masculina na dança clássica: do preconceito aos palcos da vida. Reflexão e Ação, Santa Cruz do Sul, v. 21, n.1, p. 219-236, jan./jun. 2013. Disponível em: $<$ https://online.unisc.br/seer/index.php/reflex/article/view/3354/2918>. Acesso em: 05 ago. 2016.

SCOTT, J. Gênero: uma categoria útil de análise histórica. Educação \& Realidade, Porto Alegre, v. 20, n. 02, jul./dez. 1995.

SOUZA, A. B. Representações de gênero e sexualidade associadas à dança: a cultura ensinando (e delimitando) quem pode (e onde) dançar. In: Seminário Internacional Fazendo Gênero 7, 2006, Florianópolis/SC. Anais do Seminário Internacional Fazendo Gênero 7, 2006. Disponível em: <http:// www.portalanpedsul.com.br/admin/uploads/2006/Curriculo_e_Saberes/Painel/07_30_oo_ PA213.pdf $>$. Acesso em: 05 ago. 2016.

WELZER-LANG, D. A construção do masculino: dominação das mulheres e homofobia. Estudos Feministas, Florianópolis, v. 9, n. 2, p. 460-482, 2001.

\section{SOBRE OS AUTORES}

Anderson Ferrari é graduado em História (Universidade do Estado do Rio de Janeiro), com Mestrado em Educação (Universidade Federal de Juiz de Fora) e doutorado em Educação (Universidade Estadual de Campinas). É professor pesquisador na Universidade Federal de Juiz de Fora. Tem experiência na área das relações de gênero, sexualidade e Educação, com pesquisa nos seguintes temas: homossexualidades masculinas e escolas; sexualidades e artefatos culturais; gênero, sexualidade, cinema e educação.

E-mail: aferrari13@globo.com.

Marcos Lopes de Souza é licenciado e bacharel em Ciências Biológicas (Universidade de São Paulo), com Mestrado e Doutorado em Educação (Universidade Federal de São Carlos). É professor pesquisador na Universidade Estadual do Sudoeste da Bahia. Tem experiência na área de Educação, trabalhando com os seguintes temas: ensino de ciências e biologia e diversidade de gênero, sexual e étnico-racial; formação docente e questões de gênero e sexualidade e sexismo, racismo e homofobia nas escolas.

E-mail: markuslopessouza@gmail.com.

Roney Polato de Castro é licenciado em Biologia (Universidade Federal de Juiz de Fora), com Mestrado e Doutorado em Educação (Universidade Federal de Juiz de 
Fora). É professor pesquisador na Universidade Federal de Juiz de Fora. Líder do GESED (Grupo de Pesquisa em Gênero, Sexualidade, Educação e Diversidade), tem experiência na área das relações de gênero, sexualidade e Educação, com pesquisa nos seguintes temas: gênero, sexualidade e escola; sexualidade.

E-mail: roneypolato@gmail.com.

Recebido em 27 de janeiro de 2018 e aprovado em 22 de março de 2018. 